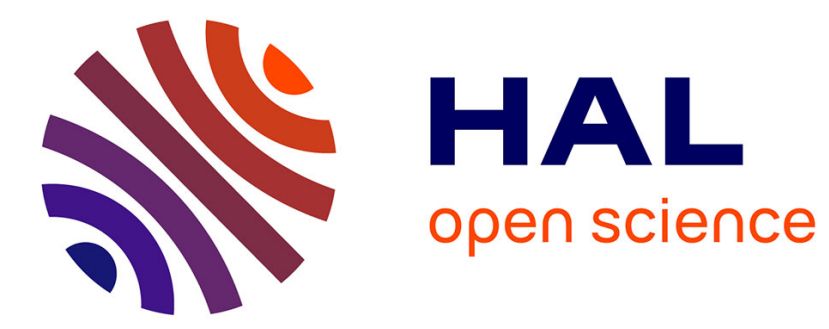

\title{
Snow satellite images for calibration of snow dynamic in a continuous distributed hydrological model
}

\author{
C. Corbari, J. Martinelli, G. Ravazzani, M. Mancini
}

\section{To cite this version:}

C. Corbari, J. Martinelli, G. Ravazzani, M. Mancini. Snow satellite images for calibration of snow dynamic in a continuous distributed hydrological model. Hydrology and Earth System Sciences Discussions, 2007, 4 (6), pp.3979-4004. hal-00298908

\section{HAL Id: hal-00298908 \\ https://hal.science/hal-00298908}

Submitted on 6 Nov 2007

HAL is a multi-disciplinary open access archive for the deposit and dissemination of scientific research documents, whether they are published or not. The documents may come from teaching and research institutions in France or abroad, or from public or private research centers.
L'archive ouverte pluridisciplinaire HAL, est destinée au dépôt et à la diffusion de documents scientifiques de niveau recherche, publiés ou non, émanant des établissements d'enseignement et de recherche français ou étrangers, des laboratoires publics ou privés. 
Hydrol. Earth Syst. Sci. Discuss., 4, 3979-4004, 2007 www.hydrol-earth-syst-sci-discuss.net/4/3979/2007/

(C) Author(s) 2007. This work is licensed under a Creative Commons License.
Hydrology and Earth System Sciences Discussions

Papers published in Hydrology and Earth System Sciences Discussions are under open-access review for the journal Hydrology and Earth System Sciences

\section{Snow satellite images for calibration of snow dynamic in a continuous distributed hydrological model}

C. Corbari, J. Martinelli, G. Ravazzani, and M. Mancini

Politecnico of Milan, Milan, Italy

Received: 17 October 2007 - Accepted: 19 October 2007 - Published: 6 November 2007

Correspondence to: C. Corbari (chiara.corbari@mail.polimi.it)

\section{HESSD}

4, 3979-4004, 2007

Snow satellite images for calibration of snow dynamic

C. Corbari et al.

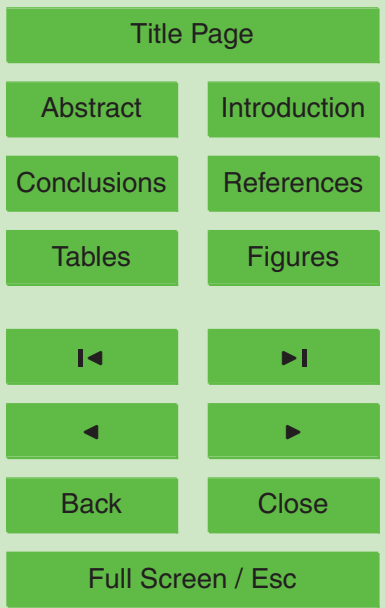

Printer-friendly Version

Interactive Discussion 


\section{Abstract}

The snow accumulation and melt processes are well known to play an important role on the river flow regime, in particular this is enhanced for basin with complex topography where the snow dynamic is strongly affected by hillslope exposition.

This paper presents a simplified numerical model for snow dynamic simulation based on air temperature thresholds that rule the snow melt and accumulation processes implemented into a continuous distributed hydrological model for hydrograph simulations at basin scale.

The possibility to calibrate these temperature thresholds from snow cover maps de10 rived from NOAA satellite images is discussed. Snow covered pixels are classified according to a procedure based on aspect and elevation of each pixel, that allows to identify snow covered pixels also in shadowed areas.

Snow model performance is proved at local and basin scale. The former shows a good agreement between modelled snow dynamic and observed snow height data at 15 the Antrona station in the Toce basin; the latter shows agreement between observed and simulated hydrographs for the three gauge stations of Toce, Ticino and Maggia rivers.

\section{Introduction}

The snow dynamic is well known to play an important role on the river flow hydrograph either for low as high discharge regimes so that its operative impact on the management of water resource in mountain basin has pushed a lot of research activities that have produced several improvement in the modelling technique (Verbunt et al., 2003; Huwald et al., 2006).

Despite its role and the capacity offered by the scientific and technical community 25
HESSD

4, 3979-4004, 2007

Snow satellite images for calibration of snow dynamic

C. Corbari et al.

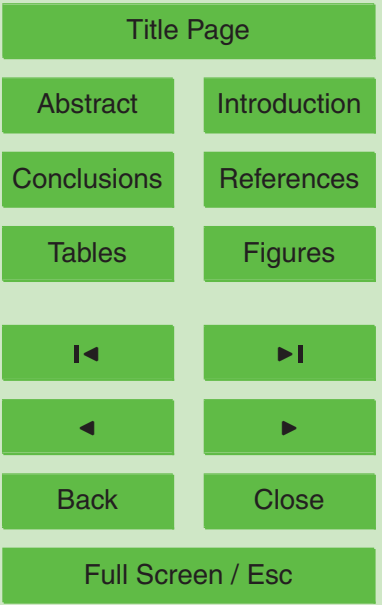

Printer-friendly Version

Interactive Discussion cover areas and its relative water equivalent due to the well known difficulties of moni- 
toring snow parameters and also to detect the snow coverage on highly topographically affected areas. The potentiality of images from remote sensing is nowadays well assessed in the scientific community, but the conversion from qualitative information to the quantitative one is still very complex. This is due to the spatial and radiometric 5 integration underlined in the pixel value of digital number given for any satellite image. This problem is evident in several field of land observation.

From the snow cycle monitoring point of view, several methodologies have been approached to improve the use of satellite ranging from synergism between numerical modelling and ground measurements of snow parameters (Bitner et al., 2002; Lee et 10 al., 2005; Ranzi et al., 1999) to more empirical relationship between flow discharge and snow accumulation and melt that explains the snow water equivalent (Martinec, 1991).

Beside the complexities of the above problems, the work proposes the well assessed use of NOAA AVHRR satellite images (NOAA, 2000) to calibrate the dynamic of snow cover modelled on alpine watersheds, where the temporal and spatial variations of snow accumulation and melting are obtained using a model parameterized on air temperature thresholds (Salandin et al., 2004). Snow covered pixels of the satellite image are classified according to a procedure based on aspect and elevation of each pixel, that allows to identify snow covered pixels also in shadowed areas.

The proposed approach is validated comparing modelled and measured snow depth evolution and modelled and observed flow hydrograph.

\section{The Lago Maggiore basin}

The Maggiore Lake, also known as Verbano, is a typical glacial basin with a total drainage area of about $6598 \mathrm{~km}^{2}$, located for $3229 \mathrm{~km}^{2}$ in the north of the Piedmont region in Italy and for $3369 \mathrm{~km}^{2}$ in Switzerland. The river network is characterised by 25 the presence of three important rivers: Ticino $\left(1616 \mathrm{~km}^{2}\right)$, Toce $\left(1534 \mathrm{~km}^{2}\right)$ and Maggia $\left(926 \mathrm{~km}^{2}\right)$ (Fig. 1).

Nearly $17 \%$ of the total area is above 2000 m a.s.l. The percentage grows up to the

HESSD

4, 3979-4004, 2007

Snow satellite images for calibration of snow dynamic

C. Corbari et al.

Title Page

Abstract Introduction

Conclusions

Tables

References

Figures

14

$\triangleleft$

Back

Close

Full Screen / Esc

Printer-friendly Version

Interactive Discussion 
$32 \%$ restricting analysis only to the River Toce basin.

Climate conditions are typically humid, characterized by higher precipitations in autumn and spring. The annual average precipitation on Toce watershed, with more than $2000 \mathrm{~mm}$, is the highest value of the whole River Po basin. Climatic characteristics, 5 together with morphology and soil texture, induced frequently flood events in the past years.

For this study, meteorological and hydrologic data were collected by the telemetric monitoring system of the Regione Piemonte, Regione Lombardia and Switzerland. Data for rainfall, air temperature, total solar direct radiation and air relative humidity 10 are available from 1 January 2000 to 31 December 2004 at hourly or sub-hourly time step. The locations of the rain gauges are shown in Fig. 2. Semi hourly data of the discharges at the three main outlets, Candoglia, Solduno and Bellinzona (Fig. 1), are available from 1 January 2000 to 31 December 2003.

Digital cartographic data were collected: the Digital Elevation Model (DEM) available 15 at $50 \times 50$ m resolution; CORINE land cover maps for the Italian part updated in the year 2000 available in vector format and CORINE maps for the Switzerland part updated in the year 1990 available in raster format; pedologic classifications for soils available in vector format. Starting from available thematic layers, all the necessary map parameters were produced in raster format at a spatial resolution of $500 \times 500 \mathrm{~m}$. These include: Curve Number, flow direction, slope and aspect, residual and saturated soil moisture, albedo, pore size distribution index, saturated hydraulic conductivity, wilting point, field capacity and soil depth.

\subsection{Snow data: satellite images and ground measurements}

The satellite images for this study are from the polar satellites NOAA-AVHRR belonging 25

to both the accumulation period and, most frequently, to the melting period. These
images are characterized by good spatial resolution $(1100 \times 1100 \mathrm{~m})$, and provide high
frequency information, in fact they pass twice a day above the same zone. For this study we considered only daily images and without clouds.
HESSD

4, 3979-4004, 2007

\section{Snow satellite images} for calibration of snow dynamic

C. Corbari et al.

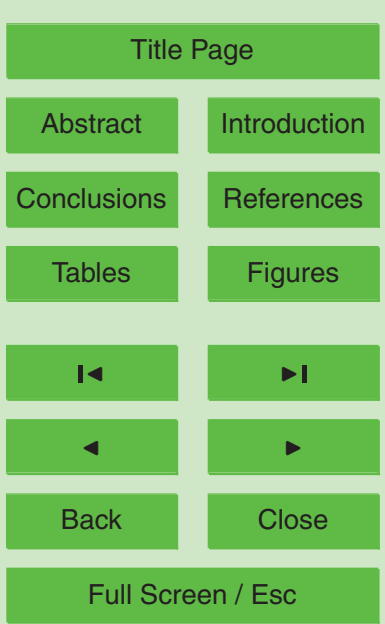

Printer-friendly Version

Interactive Discussion 
For ground measurements of snow height, we use snow gauges located only in the Toce basin over $2000 \mathrm{~m}$ of altitude available for the period of simulation.

\section{The hydrological model}

For this work FEST-WB, a distributed hydrological water balance model, was developed 5 starting from the event based models FEST98 and FEST04 (Mancini, 1990; Montaldo et al., 2007). FEST-WB computes the main processes of the hydrological cycle: evapotranspiration, infiltration, surface runoff, flow routing, subsurface flow and snow dynamics (Fig. 2). The computation domain is discretized with a mesh of regular square cells in every of which water fluxes are calculated. Soil moisture, $\theta$, evolution for the generic 10 cell at position $i, j$, is described by water balance equation:

$\frac{\partial \theta_{i, j}}{\partial t}=\frac{1}{Z_{i, j}}\left(P_{i, j}-R_{i, j}-D_{i, j}-E T_{i, j}\right)$

where $P$ is precipitation rate, $R$ is runoff flux, $D$ is drainage flux, $E T$ is evapotranspiration rate and $Z$ is the soil depth.

Runoff is computed according to a modified SCS-CN method extended for continu15 ous simulation (Ravazzani et al., 2007) where the potential maximum retention, $S$, is updated at the beginning of storm as a linear function of the degree of saturation, $\theta$.

$S=S_{1} \cdot(1-\varepsilon)$

where $S_{1}$ is the maximum value of $S$ when the soil is dry (AMC 1).

The actual evapotranspiration, $E T$, is computed as a fraction of the potential rate 20

\section{HESSD}

4, 3979-4004, 2007

Snow satellite images for calibration of snow dynamic

C. Corbari et al.

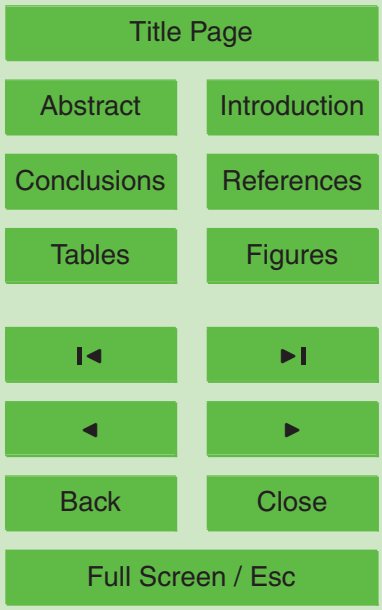

Printer-friendly Version

Interactive Discussion of clouds; moreover, in mountain basins, topographic characteristics, such as slope and aspect, may have a relevant role. In fact topography affects radiation field in three 
ways (Fig. 3): modulating the actual energy flux according to the relative position of the ground surface respect to the sun, reducing radiation because of shadowing effect of the higher crests and increasing net radiation by the fraction reflected from neighbour terrains.

5 Total radiation involved in evaporative processes $\left(R_{n}\right)$ is the sum of short wave and long wave $\left(L_{n}\right)$ net radiation:

$R_{n}=(1-r) S_{i n}+L_{n}$

$S_{i n}=Q_{a}+D F+A$

where $r$ is the surface albedo, $S_{i n}$ is the incident short wave radiation, sum of actual direct radiation, $Q_{a}$, of the scattered component, $D F$, and of the radiation reflected from neighbour terrain, $A$.

For clear sky condition the incoming solar radiation reaching the ground in the normal direction is (Fig. 3):

$I_{c}=I_{0} \exp [-s / \sin (h)] \sin (h)$

15 Where $I_{0}$ is extraterrestrial radiation at top of atmosphere (solar constant), $\mathrm{h}$ is the solar elevation angle, $s$ is the atmosphere optical depth computed as $s=s_{o} P_{h} / P_{O}$ where $s_{O}$ is the optical depth at the sea level (Kreider and Kreith, 1975) and $P_{h} / P_{o}$ is the correction of the atmospheric pressure.

$\frac{P_{h}}{P_{o}}=\left(\frac{288-0.0065 \cdot z}{288}\right)^{5.256}$

20 The scattered radiation for clear sky condition, $D$, is:

$D=k\left(I_{0} \sin (h)-I_{c}\right)$

where $k$ varies from 0.2 to 0.6 according to the sky brightness.

HESSD

4, 3979-4004, 2007

Snow satellite images for calibration of snow dynamic

C. Corbari et al.

Title Page

Abstract

Introduction

Conclusions

References

Tables

Figures

14

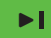

4

Back

Close

Full Screen / Esc

Printer-friendly Version

Interactive Discussion 
In clear sky condition, theoretical radiation observed at the ground level is:

$R^{*}=I_{C}+D$

The presence of clouds or natural obstacles reduces direct radiation $I_{C}$ and modifies scattered one so that $R^{*}$ can be reduced to a minimum fraction, $p$, of $R^{*} \quad(p=0.22$ 5 usually). When the observed radiation $\left(R_{\text {obs }}\right)$ is less or equal to $p R^{*}$, radiation is considered totally scattered (totally cloud covered sky). Otherwise, the fraction of scattered radiation, $K_{t}$, is computed as:

$K_{t}=\frac{R^{*}-R_{\mathrm{obs}}}{\left[(1-p) R^{*}\right]}$

Finally, actual scattered radiation component, $D F$, can be computed as:

$D F=\min \left[R_{\mathrm{obs}}, D \cdot\left(1-K_{t}\right)+R_{\mathrm{obs}} \cdot K_{t}\right]$

and direct radiation component, $Q$, as:

$Q=R_{\text {obs }}-D F$

Direct radiation component, $Q$, is affected by topographic characteristics, such as slope, $\alpha$, and aspect, $E$. Actual direct radiation, $Q_{a}$, is related to the sun elevation, 15

$Q_{a}=\frac{Q \cos (T)}{\sin (h)}$

where $T$ is the angle between the sunbeam direction and the perpendicular to the ground evaluated with:

$\cos (T)=\cos (h) \cdot \sin (\alpha) \cdot \cos (B-E)+\sin (h) \cdot \cos (\alpha)$

20 where $B$ is the solar azimuth (Fig. 2).
HESSD

4, 3979-4004, 2007

Snow satellite images for calibration of snow dynamic

C. Corbari et al.

Title Page

Abstract

Introduction

Conclusions

References

Tables

Figures

14

$$
\rightarrow
$$

4

Back

Close

Printer-friendly Version

Interactive Discussion 
The radiation reflected from neighbour terrain is:

$A=Q_{a} \cdot r \cdot\left(1-f_{\alpha}\right)$

where $f_{\alpha}=1-\alpha / 180^{\circ}$.

A module was developed to take into account the shadow effect induced by higher 5 crests. The algorithm calculates the angle, $\psi$, between the point, denoted by coordinate $x_{m}, y_{m}, z_{m}$, with maximum elevation in the direction of the solar beam, and the examined cell, denoted by coordinated $x_{0}, y_{0}, z_{0}$ (Fig. 2):

$\psi=\operatorname{arctg}\left[\left(z_{m}-z_{o}\right) / \sqrt{\left(x_{m}-x_{o}\right)^{2}+\left(y_{m}-y_{o}\right)^{2}}\right]$

If $\psi$ is higher then the sun elevation, the cell is shadowed and the incident short wave 10

$S_{i n}=D F$

When longwave net radiation measurement lacks, it is evaluated as a function of air temperature, $T_{a}$ and cloud cover fraction, $c /$ (Goudriaan,1977):

$L_{n}=-\sigma\left(T_{a}+273.15\right)^{4}\left(0.56-0.079 \sqrt{e_{a}}\right)(0.1+0.9 c /)$

15 where $\sigma$ is the Stefan-Boltzman constant, $e_{a}$ is the actual vapour pressure and $c /=1-K_{t}$.

The surface and subsurface flow routing is made by a scheme based on the Muskingum-Cunge method in its non-linear form with the time variable celerity (Montaldo et al., 2007).

The snow model includes the snow melt and the snow accumulation dynamics. The partitioning of total precipitation, $P$, in liquid, $P_{l}$, and solid, $P_{S}$, phase is a function of air temperature, $T_{a}$ (Tarboton et al., 1994):

$P_{I}=\alpha_{P} P$
HESSD

4, 3979-4004, 2007

Snow satellite images for calibration of snow dynamic

C. Corbari et al.

Title Page

Abstract

Introduction

Conclusions

References

Tables

Figures

14

$\rightarrow$

4

Back

Close

Full Screen / Esc

Printer-friendly Version

Interactive Discussion 
where $\alpha_{P}$ is computed by:

$$
\begin{cases}\alpha_{P}=0 & \text { if } T_{a} \leq T_{\text {inf }} \\ \alpha_{P}=1 & \text { if } T_{a} \geq T_{\text {inf }} \\ \alpha_{P}=\frac{T_{a}-T_{\text {inf }}}{T_{\text {sup }}-T_{\text {inf }}} & \text { if } T_{\text {inf }} \leq T_{a} \leq T_{\text {sup }}\end{cases}
$$

where $T_{\text {inf }}$ and $T_{\text {sup }}$ are calibrated parameters.

5 The snow melt simulation is based on the degree day concept (Martinec et al., 1960). The melt rate in $\mathrm{m} / \mathrm{s}, M_{s}$, is proportional to the difference between air temperature and a predefined threshold temperature, $T_{b}$ :

$M_{s}=C_{m}\left(T_{a}-T_{b}\right)$

where $C_{m}$ is an empirical coefficient depending on meteorological conditions and geo10 graphic location.

Also air temperature is affected by topography. Spatial distribution of local measurements have to consider the reduction of temperature with altitude. In the model a constant lapse rate is taken $\left(-0.0065^{\circ} \mathrm{Cm}^{-1}\right)$. Thermal inversion phenomena are neglected. A special algorithm is implemented: (1) the air temperature measurements 15 at ground level are moved to a reference height (1000 m a.s.l.) accounting for thermal gradient, (2) local measurements are spatial interpolated and (3) air temperature in each cell is taken back to the ground level considering the thermal gradient.

\section{Snow subroutine validation at local scale}

The implemented snow model gives as output not the real height of the snow pack but 20 its water equivalent; instead the ground measurements are expressed in real height. So there is a problem of direct comparison of the results. However these parameters are closely related by the snow density that is very changeable (Diamond and Lowry,

Snow satellite images for calibration of snow dynamic

C. Corbari et al.

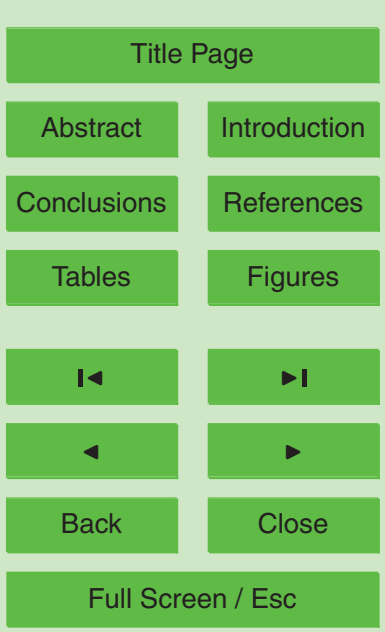

Printer-friendly Version

Interactive Discussion 
1953); in fact after falling down, snow tends to increase its density and at the same time to decrease the height due to the compression under its weight and to the continuous structural changes. In fact for fresh snow the density can be approximate to $100 \mathrm{~kg} / \mathrm{m}^{3}$, while passing of the time density can increase three or four times till values between 5400 and $500 \mathrm{~kg} / \mathrm{m}^{3}$.

Therefore here in we look for the correct spotting of the accumulation and melt period on the base of the two temperature thresholds, $T_{\text {sup }}$ and $T_{\text {inf }}$, that rule, in the used model, the snow dynamic.

In the following graph (Fig. 4) a comparison of normalized snow depth is reported 10 for the Antrona station in the Toce basin. The better couple of parameters values ( $T_{\text {sup }}=0^{\circ} \mathrm{C}$ and $T_{\text {inf }}=-3^{\circ} \mathrm{C}$ ) are estimated maximising the $R^{2}\left(R^{2}=0.85\right)$ of the linear regression between observed and simulated normalized snow depth.

In Fig. 5 the temporal dynamic is also shown and we see that the model succeeds in hitting with a good precision the accumulation and melt periods.

\section{Snow subroutine validation at basin scale}

\subsection{Snow cover classification from satellite for complex topography}

It's easy to classify snow covered pixels from satellites images for clear sky conditions due to the high reflectivity of snow in the visible band. In fact in this spectral band snow has higher values than all the others type of ground covers (Choudhury, 1979). Snow covered pixels were classified with a supervised approach from the visible band.

However some anomalies were encountered, mostly where surface was covered by a mixture of soil and snow, over densely forested areas (Voigt et al., 1999) and also in those pixels which resulted in sun shadowed area (Simpson et al., 1998; Baral and Gupta, 1997). Another problem was the presence of clouds, as their reflectivity is very similar to the snow one in the visible band even though they are much more reflective than snow in the IR band (Henderson and Sellers, 1984). In all these complex
HESSD

4, 3979-4004, 2007

Snow satellite images for calibration of snow dynamic

C. Corbari et al.

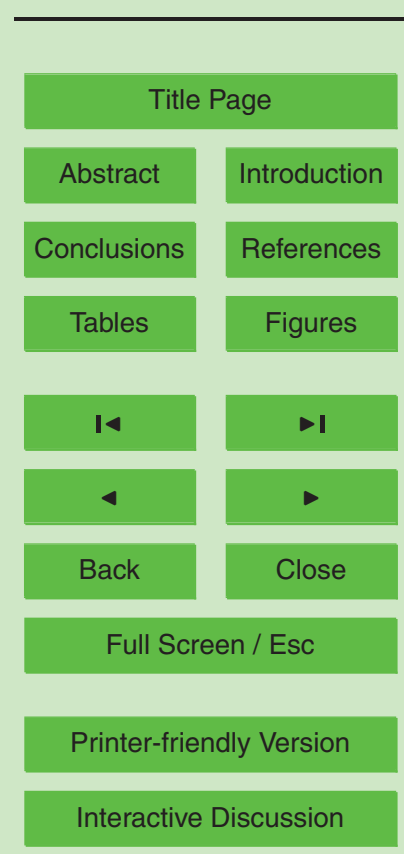

EGU 
situations, we frequently noted that area covered by snow were classified as no covered pixels.

Influence of higher crests induced shadow on pixel classification is shown in Fig. 6. A zoom of a subset of the entire basin, presented in Fig. 7, is characterized by the highest

5 elevations in the whole basin (Monte Rosa, $4472 \mathrm{~m}$ a.s.l.). Digital elevation model was resampled at the same spatial resolution of NOAA images. A map of sun shadowed pixels was produced related to the time when satellite image was taken, and it was compared to the snow coverage resulted from pixel classification. A strong correlation is shown between sun shadowed pixels and pixels classified as not covered by snow 10 but actually covered. In order to reduce anomalies in recognizing snow covered pixels, an elevation based correction was applied. According to this method all pixels above a reference altitude were considered as snow covered. Reference altitude is fixed as the mean altitude of snow on the satellite image. The basic assumption is that if a pixel is classified as not covered but, in the nearby, a covered pixel at lower elevation exists, a correction is applied.

\subsection{Comparison between simulated maps and satellite images}

Accumulation temperature related parameters in Eq. (19), $T_{\text {inf }}, T_{\text {sup }}$, were calibrated comparing simulated snow cover extent with the one retrieved from satellite images.

For snow melt, instead, we assumed $0^{\circ} \mathrm{C}$ for the $T_{b}$ parameter in Eq. (20) and 5.5 10 208 for $C_{m}$ (Salandin et al., 2004). Extreme temperatures $T_{\text {sup }}$ and $T_{\text {inf }}$ were changed in the range $3^{\circ} \mathrm{C} \div-3^{\circ} \mathrm{C}$. From different simulations, as shown in Fig. 7 , the accumulation parameters that better represent the real extent of snow covered areas are: $-3^{\circ} \mathrm{C}$ for $T_{\text {inf }}$ and $0^{\circ} \mathrm{C}$ for $T_{\text {sup }}\left(R^{2}=0.777\right)$.

These values confirm those obtained from calibration based on local scale snow 25 height data.

As an example, Fig. 8, shows the results of the comparison of the spatial distribution of snow covered areas between the model and the observations for the better parameters. In fact if we make a difference between the satellite and the simulated images, the

HESSD

4, 3979-4004, 2007

Snow satellite images for calibration of snow dynamic

C. Corbari et al.

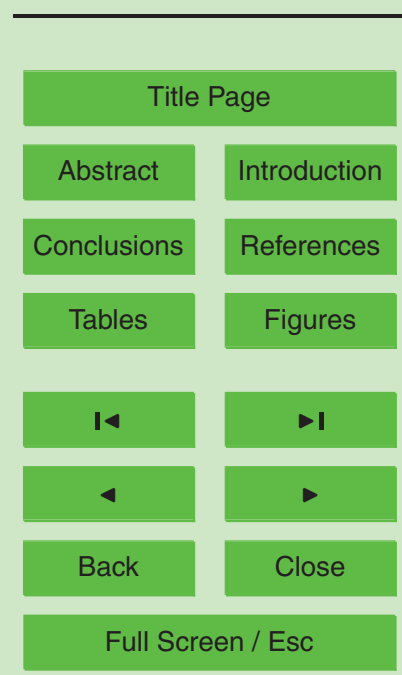

Printer-friendly Version

Interactive Discussion 
$89 \%$ of the pixels are in correspondence of coverage, the $2 \%$ of the simulated pixels are snow covered but the satellite ones not and the remaining percentage of $9 \%$ refers to the snow cover pixels in the satellite image but not in the simulated one.

\section{The role of snow dynamic in the flow regimes}

5 The flow in alpine basins is mainly influenced by the melt of glacier and snow and by its accumulation, as well as the meteorological conditions and the soil characteristics. In fact in winter the most part of rain is cumulated as snow, while on the contrary during the melt months snow is the major contributor of rivers runoff. So this flow in alpine regions is characterized by very strong daily and seasonal fluctuations (Gurtz et al., 10 2002).

However, some uncertainties still remain. One of the main uncertainties lies in the determination of the snow cover and the water equivalent, task that becomes more and more difficult on highly topographically affected areas.

The results of the used model confirm the importance of studying the snow cycle; 15 in fact, in some case, the difference between the simulated discharge considering or not the melt/accumulation of snow is evident. Melt contribution is very important both for cumulated volumes and for peaks discharge. These values are extremely variables because they strictly depend on climatic conditions of each period and on basin topographic conditions.

20 This effect of snow dynamic on discharge simulation is shown in Fig. 9. The graphs refer to a flood event period occurred at the three studied sections, precisely of November 2002 for Candoglia and of May 2002 for Solduno and Bellinzona. In the graphs three series are compared: observed discharge, discharge simulated without considering the effect of the snow accumulation and melting (turning off the snow model) and discharge simulated by means of the complete hydrological model, thus modelling snow accumulation and melting too. Data are extracted from the continuous simulation of the period 2000-2003. We see that (Fig. 9) the complete hydrological model can

\section{HESSD}

4, 3979-4004, 2007

Snow satellite images for calibration of snow dynamic

C. Corbari et al.

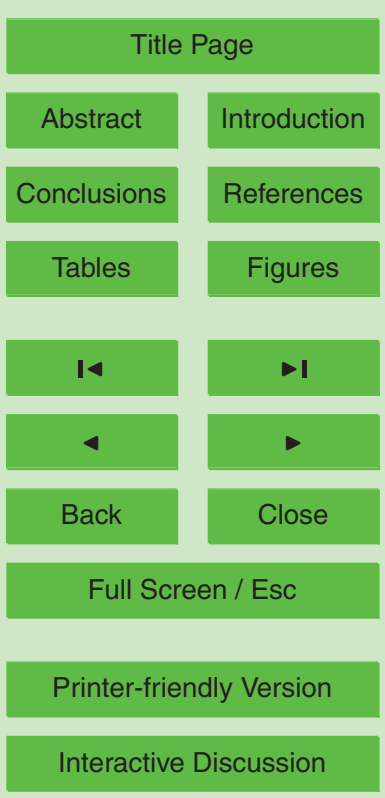

EGU 
better fit the observed discharge hydrograph and a good accuracy is retained on the simulation of the cumulated flow volume. Time to peak is good evaluated as well.

In Fig. 10 histograms of discharges errors and of volumes errors for simulated events with the snow model and without the snow model for the three control cross sections 5 of Candoglia, Solduno and Bellinzona are shown.

However exceptions exist like the big event occurred on 10-18 October 2000 on the Toce catchment where the snow didn't accumulate on mountains due to the hot temperatures and so the two simulated discharges are very similar. This is certainly one of the reasons for which that flood was so relevant.

10 Instead if we compare, for the 4 years of study, the final volumes values are nearly the same but with high seasonal fluctuation (Fig. 11). And precisely the volumes calculated without considering the snow cycle, in the period from October, where the snow accumulation starts, till April, during the snow melt, result correctly higher than the volumes calculated considering the snow. During summer, instead, the simulated discharges without considering the snow cycle fit the ones computed with accumulation/melt of snow. We show it for the Toce basin at Candoglia.

\section{Conclusions}

The paper highlights the importance of snow dynamic in continuous discharge simulation for the Lago Maggiore alpine river basin. For this reason a simplified numerical 20 snow model, based on air temperature thresholds, is implemented in a distributed hydrological water balance model. In this context, the paper presents a procedure for these temperatures calibration from satellite snow cover images based on the treatment of basin shadowed pixels.

The snow model is then validated at basin scale by the comparisons of observed 25 and simulated hydrograph at a given river cross section and by the comparison of snow cover maps from satellite images and from model simulations.

\section{HESSD}

4, 3979-4004, 2007

Snow satellite images for calibration of snow dynamic

C. Corbari et al.

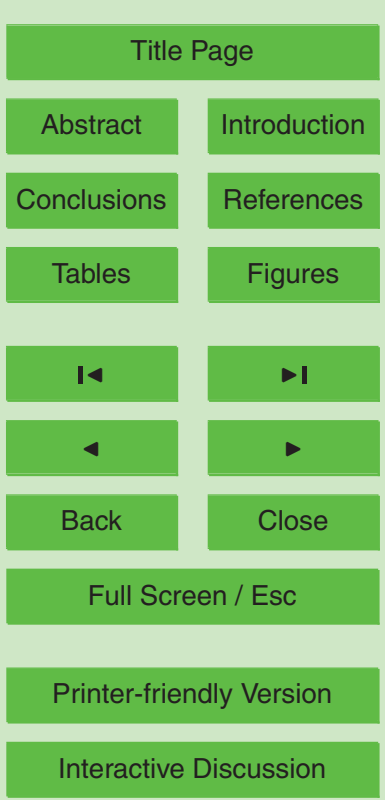




\section{References}

Baral, D. J. and Gupta, R. P.: Integration of satellite sensor data with DEM for the study of the snow cover distribution and depletion pattern, Int. J. Remote Sens., 18(18), 3889-3894, 1997.

5 Bitner, D., Carroll, T., Cline, D. and Romanov, R.: An assessment of the differences between three satellite snow cover mapping techniques, Hydrol. Process., 16, 3723-3733, 2000.

Choudhury, B. J.: Radiative properties of snow for clear sky solar radiation, Computer Sciences Corporation Report., CSC/TR-79/6025: Silver Spring, Md., 1979.

Diamond, M. and Lowry, W.: Correlation of density of new snow with $700 \mathrm{mb}$ temperature, Research paper 1, US Army Corps of Engineers, 1953.

Goudriaan, J.: Crop micrometeorology: A simulation study, Simulation monographs, Pudoc, Wageningen, 1977.

Gurtz, J., Jasper, K., and Lang, H.: Advanced flood forecasting in Alpine watershed by coupling meteorological and forecasts with a distributed hydrological model, J. Hydrol., 267, 40-52, 2002.

Henderson-Sellers, A.: Satellite sensing of a cloudy atmosphere: observing the third planet, Taylor \& Francis, London and Philadelphia, 1984.

Huwald, H., Selker, J. S., and Parlange, M. B.: Heat budget of the snow pack and interstitial exchange processes, Geophys. Res. Abstr., 8, 08356, 2006.

20 Kreider, J. F. and Kreith, F.: Solar heating and cooling: engineering, practical design, and economics, McGraw-Hill, New York, USA, 1975.

Lee, S., Klein, A., and Over, T.: A comparison of MODIS and NOHRSC snow-cover products for simulating streamflow using the snowmelt runoff model, Hydrol. Process., 19, 2951-2972, 2005.

Mancini, M.: La modellazione distribuita della risposta idrologica: effetti della variabilità spaziale e della scala di rappresentazione del fenomeno dell'assorbimento, $\mathrm{PhD}$ thesis, Politecnico di Milano, Milan, Italy (in Italian), 1990.

Martinec, J.: The degree-day factor for snowmelt runoff forecasting, proceedings of general assembly of Helsinki commission on surface waters, IAHS Publ. 51, 1960.

30 Montaldo, N., Ravazzani, G., and Mancini, M.: On the prediction of the Toce alpine basin floods with distributed hydrologic models, Hydrol. Process., 21, 608-621, 2007.
HESSD

4, 3979-4004, 2007

Snow satellite images for calibration of snow dynamic

C. Corbari et al.

Title Page

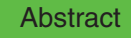

Introduction

Conclusions

Tables

References

Figures

14

I

4

Back

Close

Full Screen / Esc

Printer-friendly Version

Interactive Discussion 
NOAA: NOAA Polar Orbiter Data User's Guide: http://www2.ncdc.noaa.gov:80/docs/podug/ index.htm, 2000.

Priestley, C. H. B. and Taylor, R. G.: On the assessment of surface heat flux and evaporation using large scale parameters, Mon. Weather Rev., 100, 81-92, 1972.

5 Ranzi, R., Grossi, G., and Bacchi, B.: Ten years of monitoring areal snowpack in the Southern Alps using NOAA-AVHRR imagery, round measurements and hydrological data, Hydrol. Process., 13, 2079-2095, 1999.

Ravazzani, G., Mancini, M., Giudici, I., and Amadio, P.: Effects of soil moisture parameterization on a real- ime flood forecasting system based on rainfall thresholds, in: Quantification and Reduction of Predictive Uncertainty for Sustainable Water Resources Management, Proceedings of Symposium HS2004 at IUGG2007, Perugia, IAHS Publ. 313, 2007.

Salandin, A., Rabuffetti, B., Barbero, S., Cordola, M., Volontè, G., and Mancini, M.: II lago effimero sul ghiacciaio del Belvedere: monitoraggio e simulazione numerica del fenomeno finalizzata alla previsione e gestione dell'emergenza, Neve e Valanghe, 51, 58-65, 2004.

Simpson, J. J., Stitt, J. R., and Sienko, M.: Improved estimates of the areal extent of snow cover from AVHRR data, J. Hydrol., 204, 1-23, 1998.

Tarboton, D. G., Chowdhury, T. G., and Jackson Thomas, H.: A Spatially Distributed Energy Balance Snowmelt Model, Utah Water Research Laboratory, 1994.

Verbunt, M., Gurtz, J., Jasper, K., Lang, H., Warmerdam, P., and Zappa, M.: The hydrological role of snow and glaciers in alpine river basins and their distributed modelling, J. Hydrol., 282, 36-55, 2003.

Voigt, S., Koch, M., and Baumgartner, M. F.: A multichannel threshold technique for NOAA AVHRR data to monitor the extent of snow cover in the Swiss Alps, Interactions between the cryosphere and creenhouse, Procceedings of IUGG 99 Symposium HS2, Birmingham, IAHS Publications, 256, 35-43, 1999.

HESSD

4, 3979-4004, 2007

Snow satellite images for calibration of snow dynamic

C. Corbari et al.

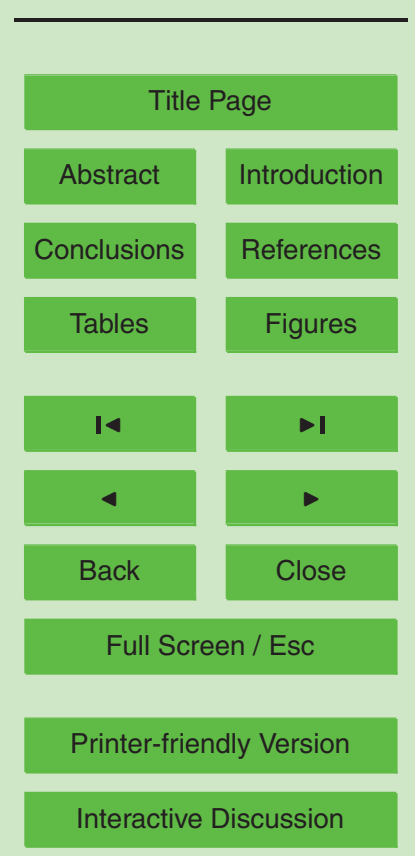

EGU 


\section{HESSD}

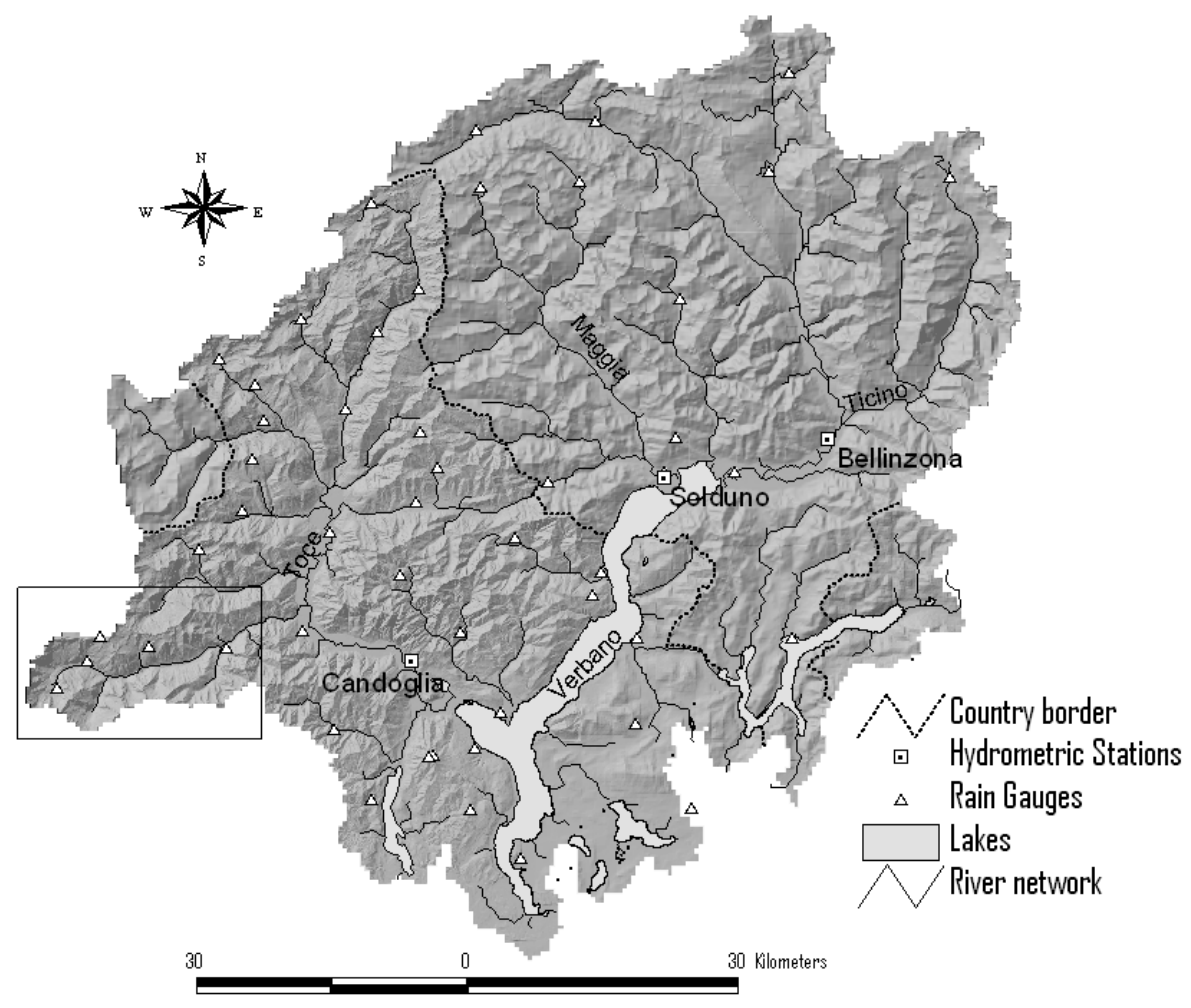

4, 3979-4004, 2007

Snow satellite images for calibration of snow dynamic

C. Corbari et al.

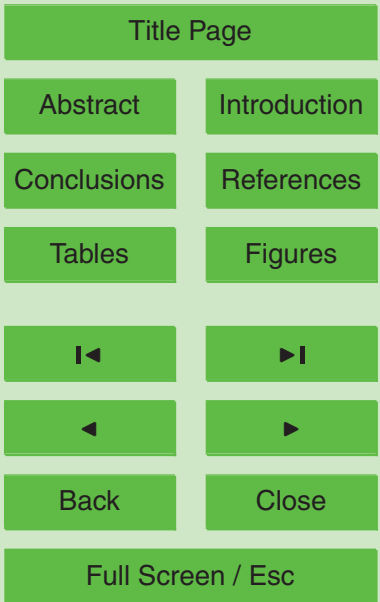

Fig. 1. The Verbano watershed extracted from the digital elevation model (DEM) showing locations of the rain gauges and hydrometric stations.

Printer-friendly Version

Interactive Discussion 


\section{HESSD}

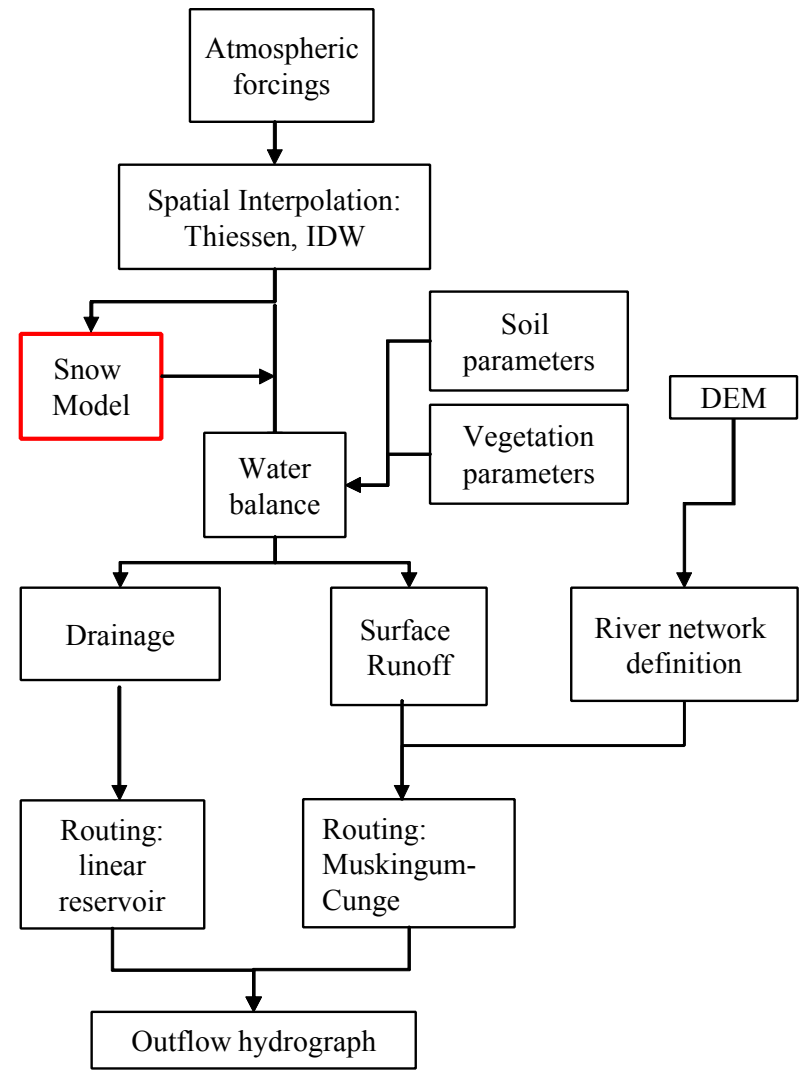

4, 3979-4004, 2007

Snow satellite images for calibration of snow dynamic

C. Corbari et al.

Title Page

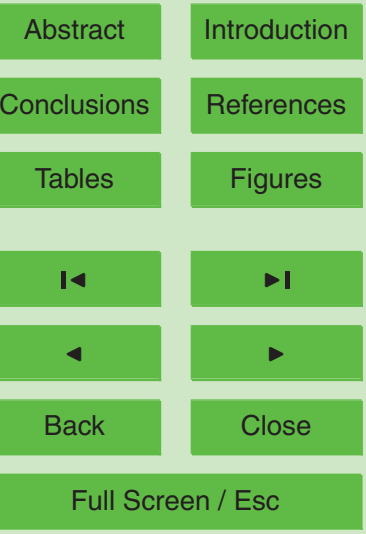

Printer-friendly Version

Interactive Discussion

Fig. 2. Scheme of the hydrological model. 


\section{HESSD}

4, 3979-4004, 2007

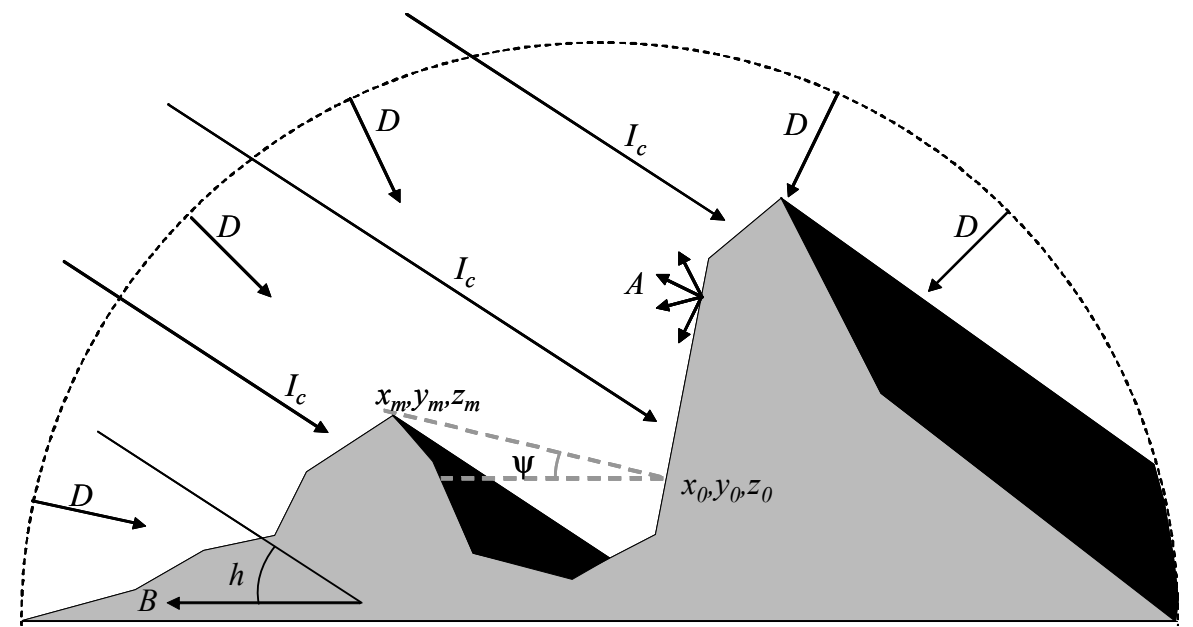

Fig. 3. Incident short wave radiation components in mountain regions for clear sky condition: direct, $I_{c}$, scattered, $D$ and reflected from neighbour terrain, $A$.
Snow satellite images for calibration of snow dynamic

C. Corbari et al.

\section{Title Page}

Abstract

Conclusions

Tables

14

4

Back
Introduction

References

Figures

$>$ I

$>$

Close
Full Screen / Esc

Printer-friendly Version

Interactive Discussion 


\section{HESSD}

\section{4, 3979-4004, 2007}

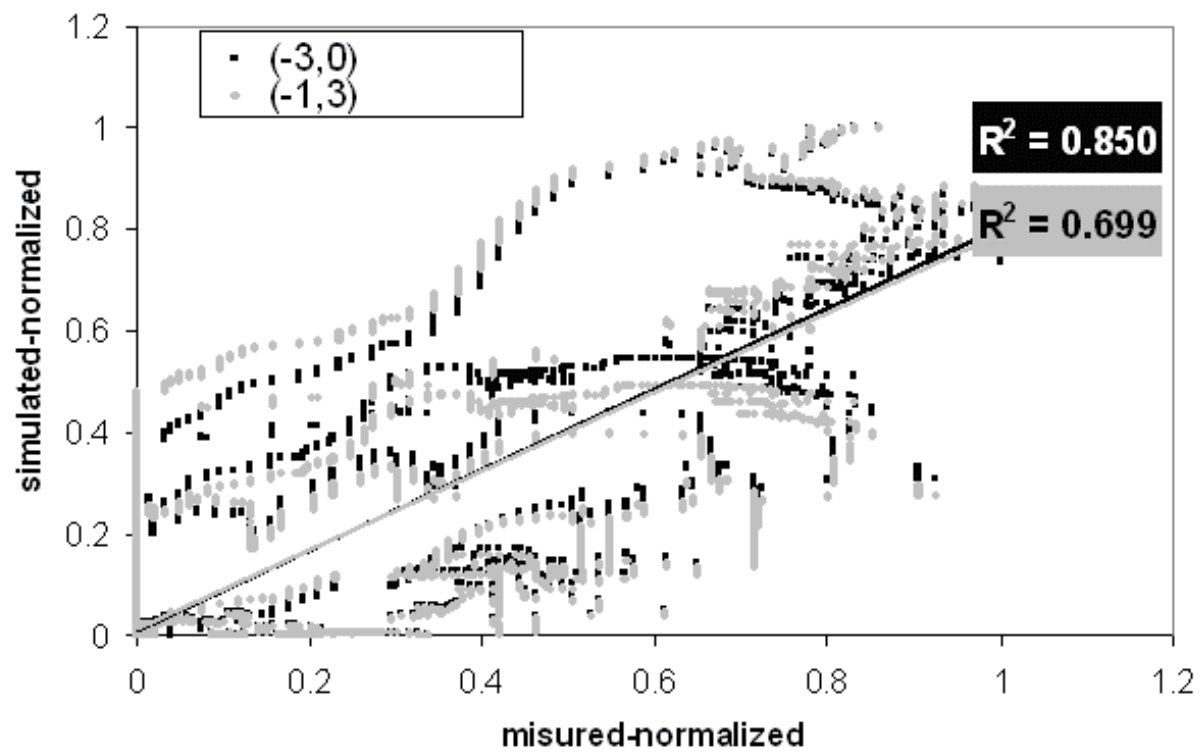

Snow satellite images for calibration of snow dynamic

C. Corbari et al.

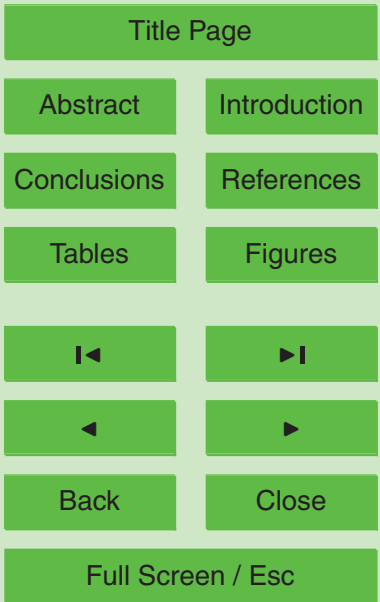

Fig. 4. Correlation between normalized measured and simulated result in Antrona Lago station for different values of $T_{\text {sup }}$ and $T_{\text {inf }}$.

Printer-friendly Version 


\section{HESSD}

\section{4, 3979-4004, 2007}

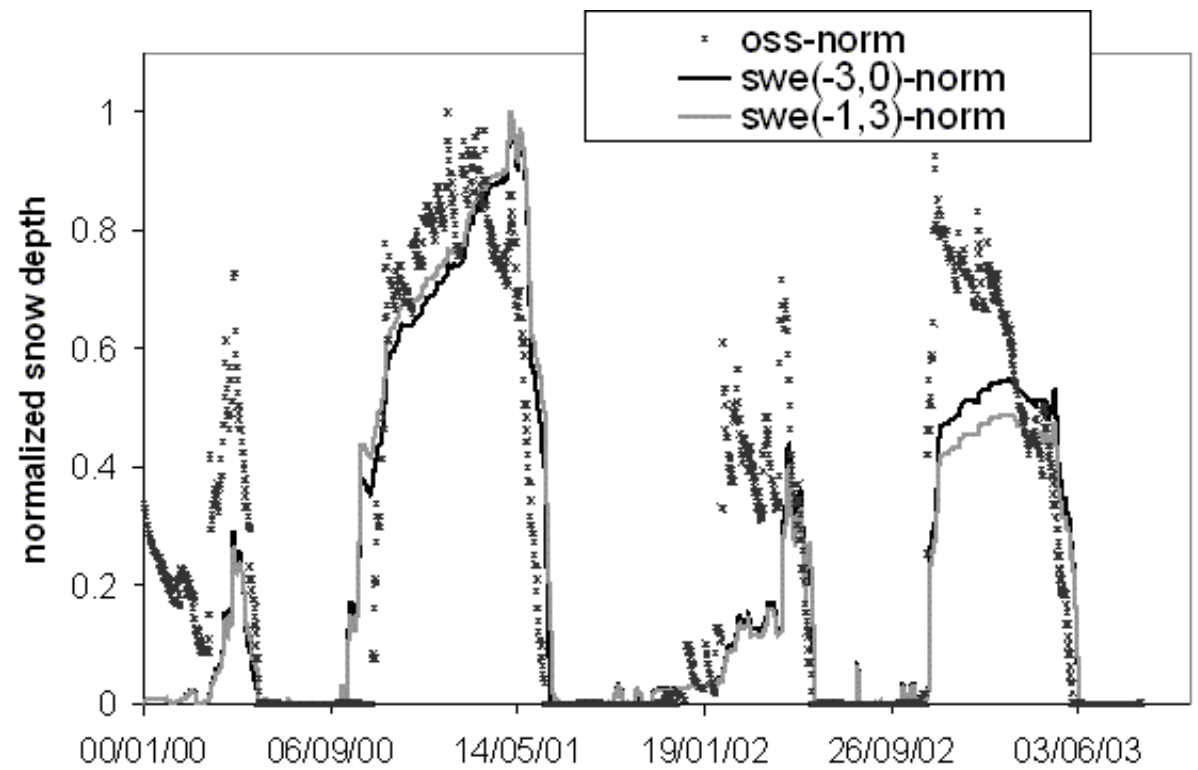

Snow satellite images for calibration of snow dynamic

C. Corbari et al.

Title Page

Abstract

Introduction

Conclusions

References

Tables

Figures

14

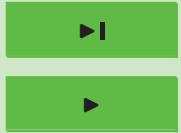

Back

Close

Full Screen / Esc

Printer-friendly Version

Interactive Discussion 


\section{HESSD}

4, 3979-4004, 2007

Snow satellite images for calibration of snow dynamic

C. Corbari et al.

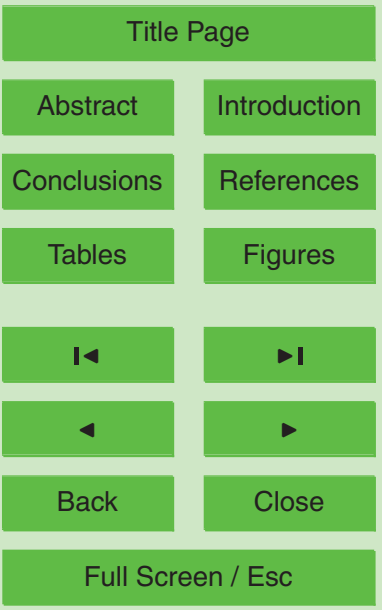

Printer-friendly Version

Interactive Discussion 


\section{HESSD}

\section{4, 3979-4004, 2007}

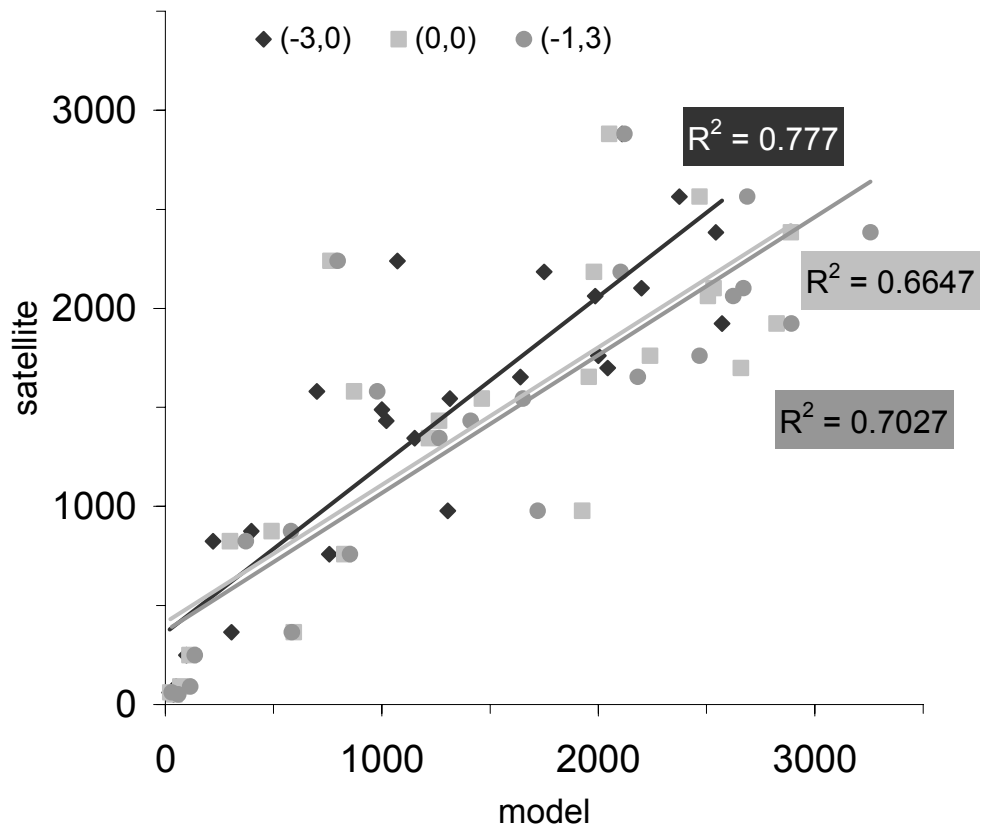

Fig. 7. Calibration of the $T_{\text {inf }}$ and $T_{\text {sup }}$ parameter. Every point is related to a certain date and time. Results for three combination are shown: $T_{\text {inf }}=-3$ and $T_{\text {sup }}=0, T_{\text {inf }}=T_{\text {sup }}=0, T_{\text {inf }}=-1$ and $T_{\text {sup }}=3$. Linear trendline are inserted. $R^{2}$ value is shown in label.
Snow satellite images for calibration of snow dynamic

C. Corbari et al.

\section{Title Page}

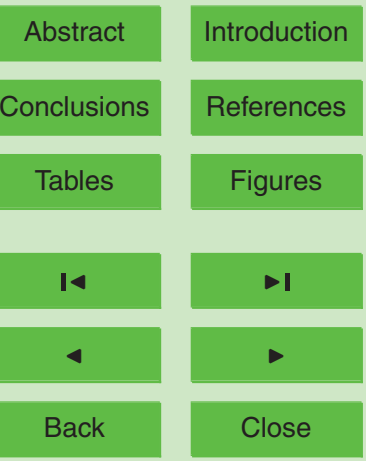

Full Screen / Esc

Printer-friendly Version

Interactive Discussion 


\section{HESSD}

4, 3979-4004, 2007
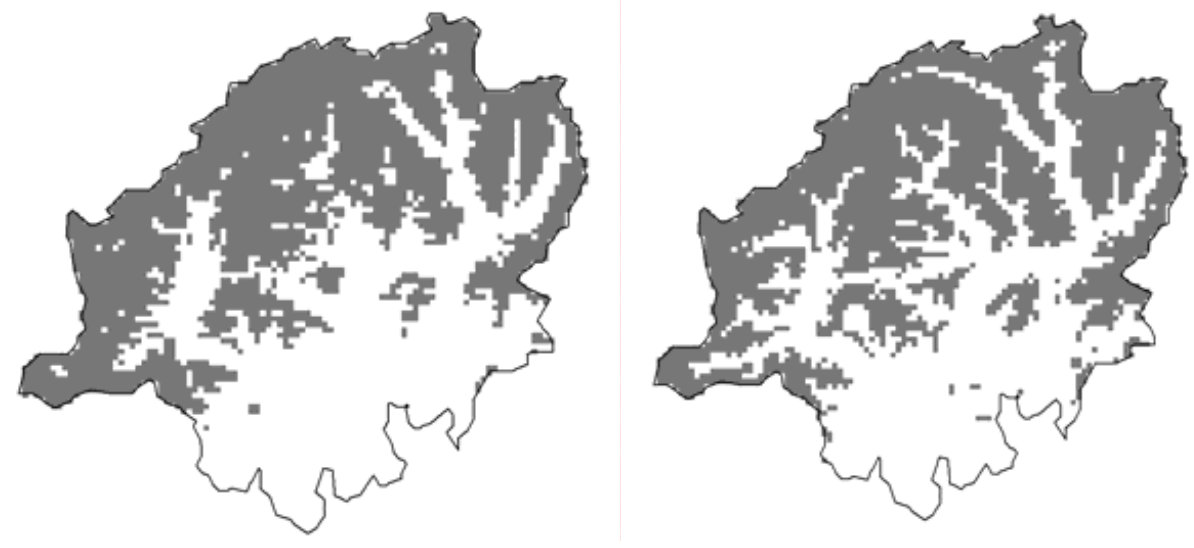

Fig. 8. Classified satellite image for 10 February 2002 at 14:30 (left) and simulated map (right) and the histogram of the number of pixels for the different type of coverage.
Snow satellite images for calibration of snow dynamic

C. Corbari et al.

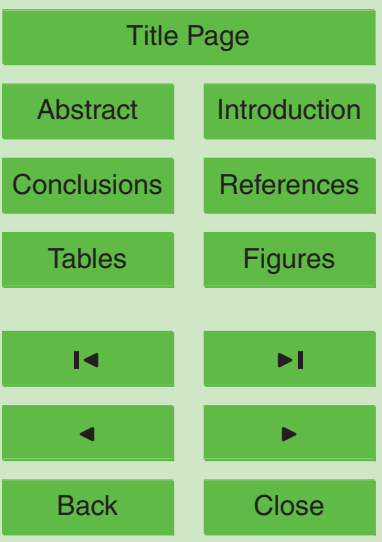

Full Screen / Esc

Printer-friendly Version

Interactive Discussion 

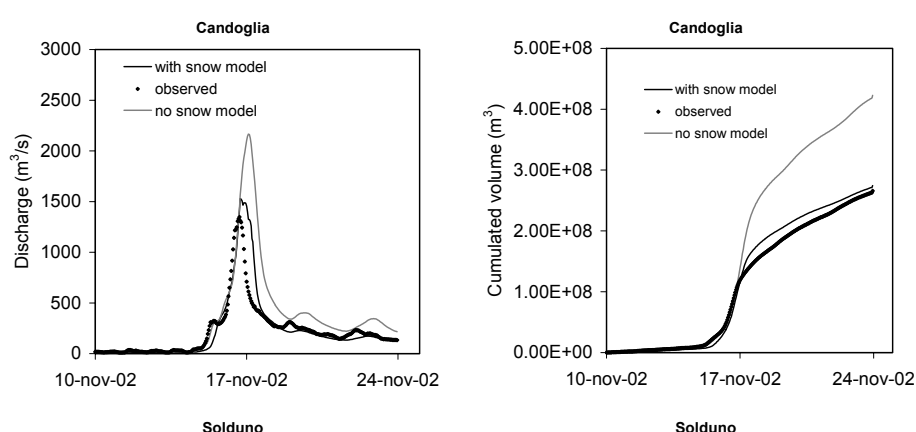

HESSD
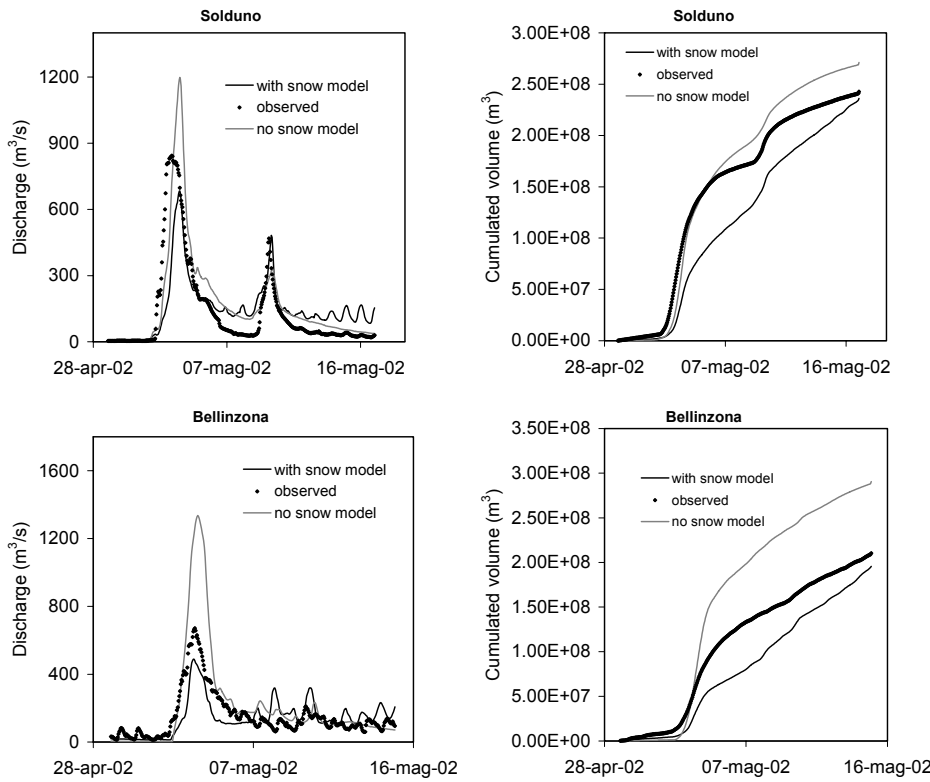

\section{4, 3979-4004, 2007}

Snow satellite images for calibration of snow dynamic

C. Corbari et al.

\section{Title Page}

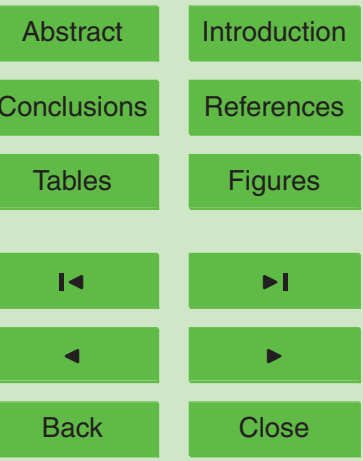

Full Screen / Esc

Printer-friendly Version

Interactive Discussion 

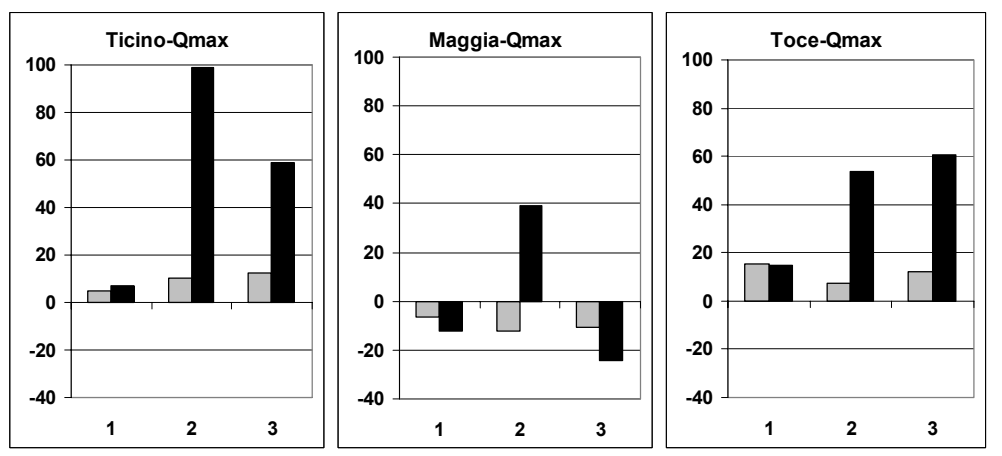

\section{4, 3979-4004, 2007}

Snow satellite images for calibration of snow dynamic

C. Corbari et al.
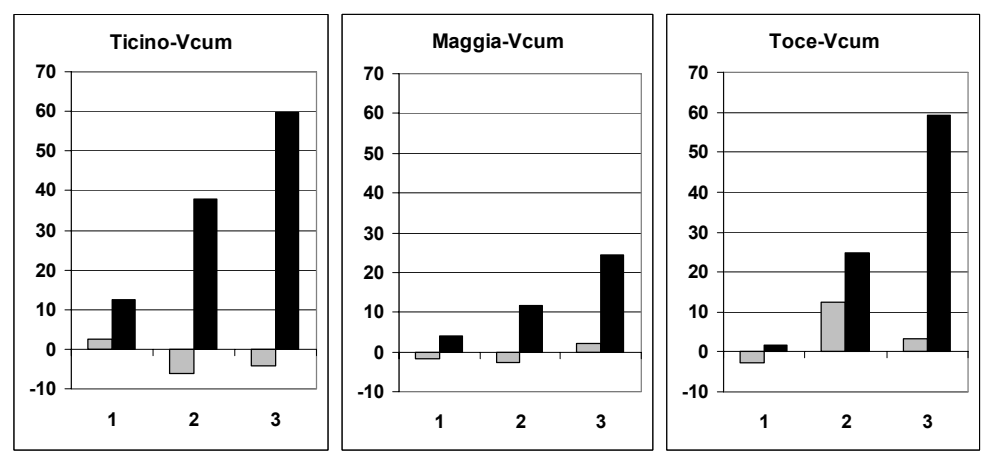

Title Page

Abstract

Conclusions

Tables

14

4

Back
Introduction

References

Figures

$>$ I

$>$

Close

Fig. 10. Histograms of discharges errors and of volumes errors for events simulated with the snow model (grey) and without the snow model (black) for the three control cross sections of Candoglia (Toce), Solduno (Maggia) and Bellinzona (Ticino). Number 1 on the $\mathrm{x}$-axis refers to the event of 11 October 2000, number 2 to 29 April 2002 and number 3 to 12 November 2002.

\section{Full Screen / Esc}

Printer-friendly Version

Interactive Discussion 


\section{HESSD}

4, 3979-4004, 2007

Snow satellite images for calibration of snow dynamic

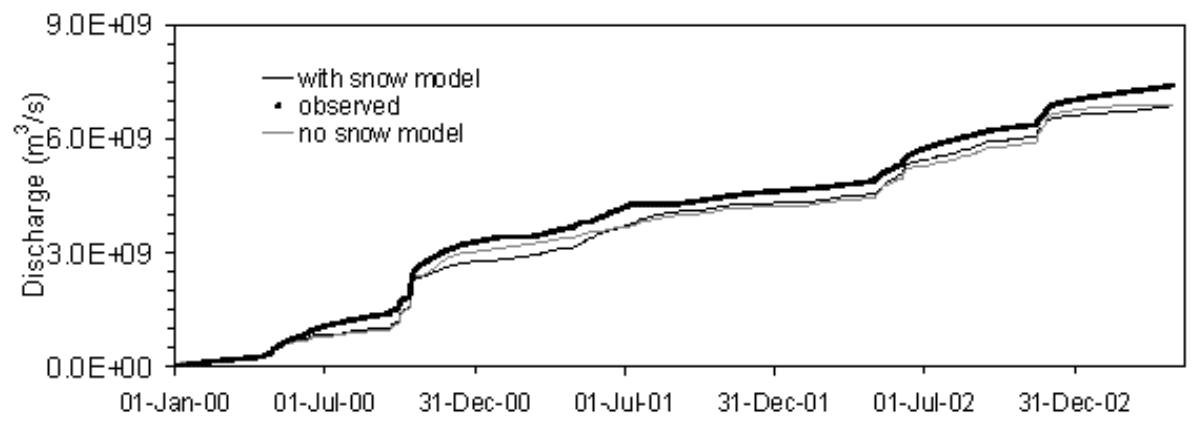

C. Corbari et al.

Title Page

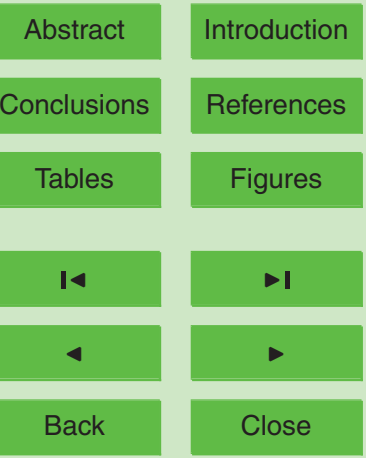

Full Screen / Esc

Printer-friendly Version

Interactive Discussion 